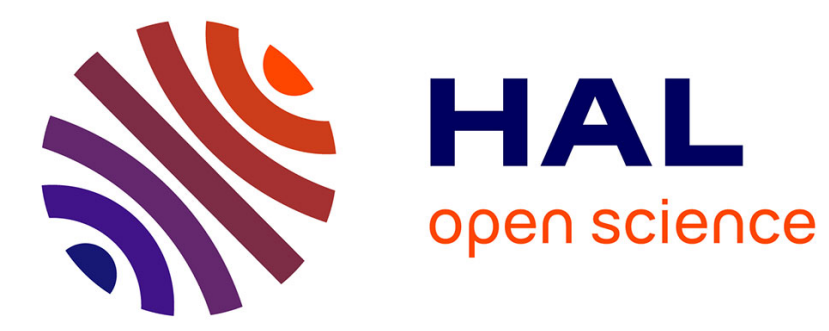

\title{
Repurposing of rutin for the inhibition of norovirus replication
}

Nicolas Chéron, Chenchen Yu, Abimbola O Kolawole, Eugene I Shakhnovich, Christiane E Wobus

\section{- To cite this version:}

Nicolas Chéron, Chenchen Yu, Abimbola O Kolawole, Eugene I Shakhnovich, Christiane E Wobus. Repurposing of rutin for the inhibition of norovirus replication. Archives of Virology, 2015, 160 (9), pp.2353-2358. 10.1007/s00705-015-2495-y . hal-02973978

\section{HAL Id: hal-02973978 https://hal.science/hal-02973978}

Submitted on 21 Oct 2020

HAL is a multi-disciplinary open access archive for the deposit and dissemination of scientific research documents, whether they are published or not. The documents may come from teaching and research institutions in France or abroad, or from public or private research centers.
L'archive ouverte pluridisciplinaire HAL, est destinée au dépôt et à la diffusion de documents scientifiques de niveau recherche, publiés ou non, émanant des établissements d'enseignement et de recherche français ou étrangers, des laboratoires publics ou privés. 


\section{Repurposing of Rutin for the Inhibition of Norovirus Replication}

Nicolas Chéron ${ }^{19}$, Chenchen $\mathrm{Yu}^{29}$, Abimbola O. Kolawole², Eugene I. Shakhnovich ${ }^{1}$, and Christiane E. Wobus ${ }^{2 *}$

${ }^{1}$ Department of Chemistry and Chemical Biology, Harvard University, Cambridge, MA, 02138, USA

${ }^{2}$ Department of Microbiology and Immunology, University of Michigan Medical School, Ann Arbor, MI, 48109, USA

*Correspondence: cwobus@umich.edu

ףThese authors contributed equally to this work. 


\section{Abstract}

Drug repurposing is a strategy employed to circumvent some of the bottlenecks involved in drug development, such as the cost and time needed for developing new molecular entities. Noroviruses cause recurrent epidemics and sporadic outbreaks of gastroenteritis associated with significant mortality and economic costs but no treatment is approved to date. Herein, a library of molecules previously used in man was screened to find compounds with anti-noroviral activity. Antiviral testing for four selected compounds against murine norovirus infection revealed that rutin has anti-murine norovirus activity in cell-based assays. 


\section{Main text}

The development cost of new drugs has exploded over the last decades and is now estimated to be at least \$2 billion per drug [27]. At the same time, the number of new molecular entities approved by FDA has saturated to about 25 per year [25]. The success rate of new molecular entities is estimated to be $10 \%$ from Phase II to market, and $50 \%$ from Phase III to market. These values increase to $25 \%$ and $64 \%$ for repositioned drugs [36]. Therefore, an increased effort is being made towards drug repurposing $[32,40,48]$, with demonstrated success in part due to the fact that different diseases can have related biological origin $[36,37,46]$. Since toxicology and pharmacokinetic data of repurposed molecules are already available, the development process is accelerated and the risk of failures is lowered.

Noroviruses (NoV) cause almost $80 \%$ of non-bacterial gastroenteritis in humans and spread quickly in confined environments, leading to $\sim 71,000$ hospitalizations and $\sim 800$ deaths every year in the USA [4, 20, 34, 41]. The impact is even greater in resource poor nations, where an estimated 200,000 children under 5 years of age die every year from NoV infections [34]. However, no specific treatments to control or prevent norovirus illness are approved by the FDA to date. Norovirus vaccine efforts are in phase I clinical trials [45], however vaccines cannot be used in some at risk populations, such as immunocompromised patients [17]. Moreover, any effective vaccine design needs to overcome the large genetic diversity and rapid mutation rate of HuNoVs [26]. Thus, the development of low-molecular weight drugs with anti-norovirus activity has emerged as another strategy to treat or prevent norovirus infections. To date, three of the nine proteins encoded by the (+)-sense, singlestranded RNA genome have been researched extensively for their potential as antiviral targets [3]: the capsid protein VP1 $[12,35]$, the protease $[24,30,44]$, and the RNA-dependent RNA-polymerase 
(RdRp) $[8,38,51]$. In the absence of a robust HuNoV cell culture system [23], murine NoV (MNV) has proved to be an attractive and widely used surrogate virus for HuNoV, including for drug development efforts [39].

To identify molecules that potentially could be repurposed as a broad spectrum norovirus antiviral, we chose molecules that have already been used in humans and docked them in silico into the MNV RdRp protein (PDB ID: 3UPF [31]). The "ZINC In Man" library was downloaded in SMILES format (http://zinc.docking.org/browse/subsets/special) [21, 22]. The 11421 molecules were converted to 15990 3D structures with LigPrep [5] by preparing different stereoisomers or protonation states. This in silico library was first docked with Glide-SP on chain B of the MNV RdRp [2, 13, 19]. The 2500 best molecules (i.e. with the lowest scores) were kept and docked with the extraprecision mode (XP) of Glide [14] on the same grid. The 37 molecules, which can be represented as 90 states (stereoisomers or tautomers), was next docked on the three chains of the MNV RdRp with the QM-Polarized Ligand Docking approach and the scores were averaged $[1,7]$. This set of 90 molecules was also docked into the human norovirus RdRp (PDB ID: 1SH2 [33]). The docking outcome was then analyzed, and we removed the molecules which appeared not promising for testing as a potential drug due to their ubiquity in cells (for example NADH or sugars). Sixteen molecules with the lowest score for MNV RdRp and the accompanying scores for HuNoV RdRp are presented in Table 1.

Based on the scores for murine and human NoV RdRp and the price of the molecules, four compounds were selected for experimental testing in cell culture: ZINC28639308 (AD132644), ZINC11726792 (Sinefungin), ZINC72206342 (Rutin), ZINC04216682 (Kasugamycin). The predicted dissociation constants of these molecules with the MNV RdRp are 1.4, 66, 78 and $588 \mathrm{nM}$, respectively. Rutin hydrate (Sigma, Cat. No. R5143) and kasugamycin hydrochloride from streptomyces kasugaensis (Sigma, Cat. No. K4013) were freshly prepared in DMSO as a $10 \mathrm{mM}$ stock 
solution or in water as a $1 \mathrm{mM}$ stock solution, respectively. Sinefungin (Sigma, Cat. No. S8559) and AD132644 (AnalytiCon Discovery, Cat. No. NP-005514) were dissolved in water as a $26.22 \mathrm{mM}$ stock solution, or in DMSO as a $10 \mathrm{mM}$ stock solution, respectively, and stored at $4^{\circ} \mathrm{C}$. Since no reproducible HuNoV cell culture model was available $[11,23]$, we tested the antiviral activity of these compounds against MNV in the murine macrophage cell line RAW 267.4 (ATCC; Manassas, VA). Cells were maintained as described previously [47], and the plaque-purified MNV-1 clone (GV/MNV1/2002/USA) MNV-1.CW3 (referred herein as MNV-1) was used at passage 6. Our first goal was to determine the cellular toxicity of the selected compounds in RAW 264.7 cells using the WST-1 assay (Roche, San Francisco, CA), which measures mitochondrial dehydrogenase activity [16]. Concentrations that maintained cell viability at or above $80 \%$ were considered non-toxic. Concentrations equal or above $100 \mu \mathrm{M}$ for rutin (Figure 1a), $0.5 \mu \mathrm{M}$ for kasugamycin (Figure 1b), $1 \mathrm{mM}$ for sinefungin (Figure 1c), and $5 \mu \mathrm{M}$ for AD132644 (Figure 1d) maintain cellular viability.

In order to identify whether the selected drugs exhibited antiviral efficacy against NoV, RAW 264.7 cells were infected with MNV-1 ( $\mathrm{MOI}$ of 2.0) in the presence of rutin, kasugamycin, sinefungin, and AD132644 at previously determined non-toxic concentrations, or equal amounts of vehicle control (i.e., $\mathrm{H}_{2} \mathrm{O}$ or DMSO) (Figure 2). RAW 264.7 cells were plated at $5 \times 10^{5}$ per well in 12 -well plates the day before. Infection occurred for $1 \mathrm{~h}$ on ice, after which the viral inoculum was removed by washing cells with ice-cold PBS three times before adding media containing one of the four drugs at indicated concentrations. Eight hours later, viral titers were determined by plaque assay as described previously [15]. A statistically significant difference between rutin and vehicle-treated cells was observed at $1 \mu \mathrm{M}$ and $100 \mu \mathrm{M}$ of drug (Figure 2a). However, no antiviral effect was observed at any of the concentrations tested for kasugamycin (Figure 2b), sinefungin (Figure 2c), and AD132644 (Figure 2d). Taken together, these data suggest that rutin but not kasugamycin, sinefungin and AD132644 
have antiviral efficacy against MNV-1 in cell culture.

Rutin is a flavonoid which belongs to the family of vitamin C2 and is found in many vegetables (olive, asparagus), fruits (raspberry, plum) or cereals (buckwheat) (http://phenolexplorer.eu/contents/polyphenol/296). It is a compound with known antioxidant [49], antiinflammatory [18] and anti-cancer effects $[9,28]$ and some of its derivatives are commercialized under the name Venoruton. To get more insight on the mechanism of action of rutin, we performed RNA synthesis assays using recombinantly expressed and purified MNV-1 and GII.4 HuNoV RdRps [50]. Surprisingly, rutin exhibited no inhibitory activity against either RdRp at all concentrations tested up to $5 \mu \mathrm{M}$ (see Supporting Information). In the same assay, benzodiathiadine, a potent non-nucleoside inhibitor of the HCV RdRp [10], inhibited RNA synthesis by the HCV RdRp at low micromolar concentrations (data not shown). To determine whether rutin acts as a prodrug, its activity was tested in a mammalian cell-based assay where transiently expressed RdRp stimulates retinoic acid-inducible gene I (RIG-I)-dependent reporter luciferase production via the beta interferon promoter [42]. Again no inhibition was observed at all concentrations tested (data shown in Supporting Information).

Therefore, we next hypothesized that rutin may be targeting another viral protein. Recent studies have reported that rutin is efficient for the inhibition of enterovirus $3 C$ protease [29], which is a picornavirus, the most closely related virus family to caliviruses. Thus, we docked rutin in the norovirus protease (PDB ID: 3UR6 [24]): the predicted $K_{d}$ was found to be of $588 \mathrm{nM}$ (docking score of -8.5). Therefore, we performed FRET-based rutin inhibition assays with the MNV-1 and GII.4 HuNoV proteases [6] at concentrations of up to $100 \mu \mathrm{M}$. Unfortunately, no inhibition of protease activity by rutin was observed (data shown in Supporting Information).

Taken together, the in vitro assays demonstrated that the antiviral activity of rutin is not mediated by the viral polymerase or protease, suggesting the antiviral activity is mediated by one or 
more of the remaining viral proteins and/or unknown cellular proteins. MNV encodes nine proteins, which all could be potential targets [43]. However, it is unlikely that rutin targets the major capsid protein VP1, as no similarities were observed between rutin and other known small molecules targeting the VP1 capsid protein (such as suramin, heparin, citrate or fucose analogs) [3]. Another potential explanation is that rutin is a prodrug of the active compound, for example via its sugar part (rutinose), which is synthesized in the cell. Moreover, amongst the non-nucleoside analog RdRp inhibitors are styrylchromones [3], which share with rutin a chromone moiety. Styrylchromones [38] are capable of inhibiting MNV replication in cell culture through an unknown mechanism, but which is hypothesized to be via targeting the RdRp. However, since the cell-based RdRp assay tests demonstrated no inhibition, it is unlikely that rutin acts as a prodrug on the MNV RdRp. At this point, we cannot rule out that rutin interacts with one of the remaining six viral proteins NS1-5, VF1 or VP2. Time of addition experiments were performed and results are presented in Figure 3 . We observed that no differences are found when $100 \mu \mathrm{M}$ of rutin are added one hour before infection, at the time of infection, one hour or four hours later. However, when $1 \mu \mathrm{M}$ of rutin is added, the $\%$ of virus titer drops from 76 to 39 depending if addition is made before infection or four hours after. These data lead us to hypothesize that rutin may act at the level of replication or later in the life cycle, but not at the stage of adhesion or internalization. Alternatively, the antiviral activity of rutin may be mediated through interaction with one or more cellular proteins needed during infection. This appears to be the most likely explanation as rutin inhibited MNV infection at a concentration of $1 \mu \mathrm{M}$ (Figure 2a), a concentration far below the cytotoxic concentration of rutin, $100 \mu \mathrm{M}$ (Figure 1a). However, identification of targets will require additional studies in the future.

In summary, we report that rutin, a flavonoid derivative, has antiviral efficacy against MNV-1 in cell culture. No inhibition was observed in in vitro assays with the viral polymerase or protease. The 
exact mechanism of action of rutin that leads to antiviral effects remains to be identified; nonetheless, we hypothesize that rutin may act at the level of replication or later in the life cycle.

\section{Acknowledgments}

This work was supported by Defense Advanced Research Projects Agency (DARPA) Contract HR001111-C-0093. The funders had no role in study design, data collection and analysis, decision to publish, or preparation of the manuscript. The authors thank Audrey E. Fischer, Joshua T. Wolfe, Jeffrey S. Lin, and Andrew B. Feldman from the Applied Physics Laboratory of John Hopkins University (MD, USA) for fruitful discussions. We further thank Xiaoyan Lin and Emma Winkler at Indiana University for performing the RdRp assays and David George at Kansas State University for performing the protease assay. The computations performed for this paper were run on the Odyssey cluster supported by the FAS Division of Science, Research Computing Group at Harvard University. 


\section{Figure Legends:}

A

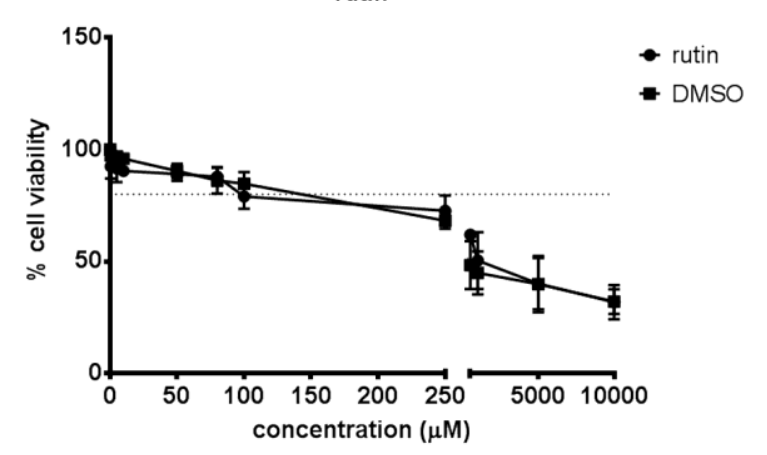

C

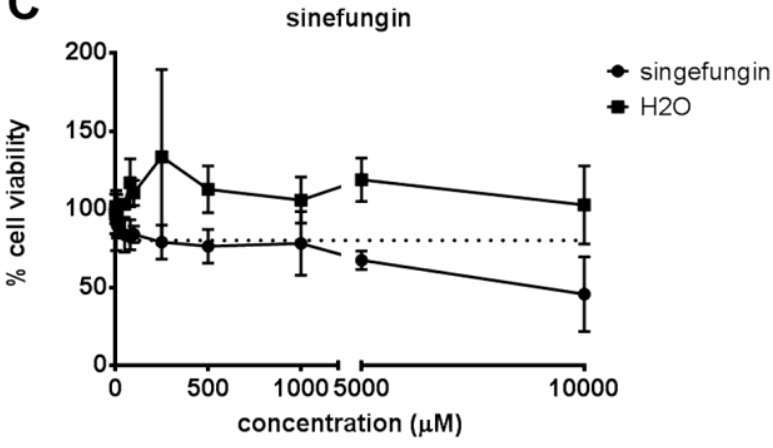

B kasugamycin

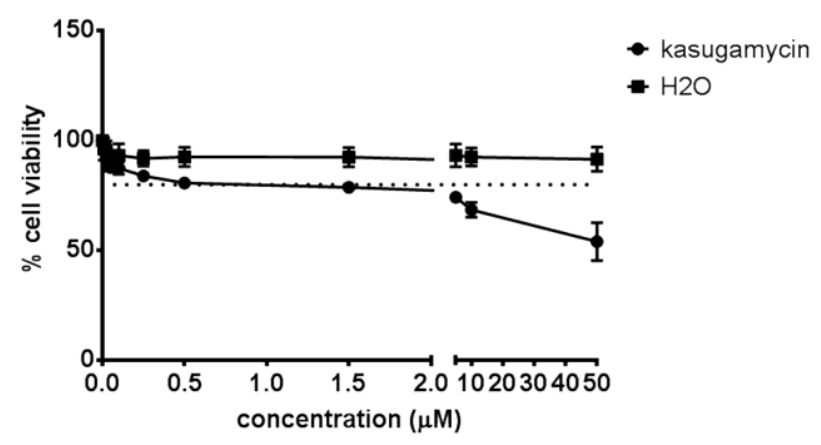

D

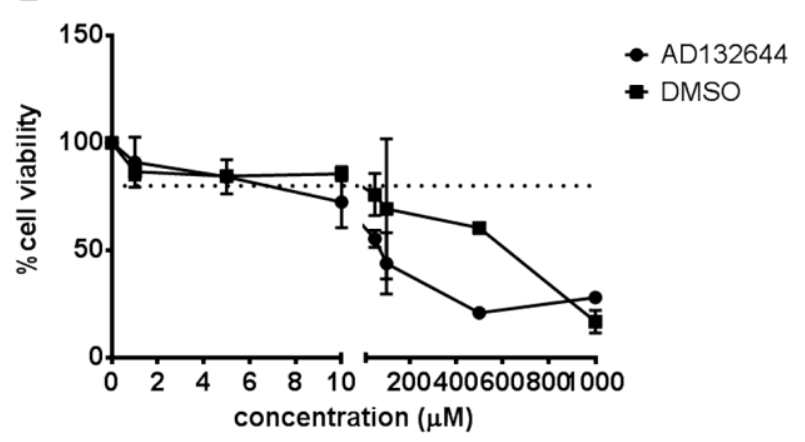

Figure 1. Cell viability following drug treatment. Cells were treated for 8 hours with indicated concentrations of (a) rutin; (b) kasugamycin; (c) sinefungin; (d) AD132644. Cells treated with vehicle were set to $100 \%$. Drug concentrations resulting in cell viability above $80 \%$ were considered safe to use and are indicated by the dashed line. Data are presented as means \pm SE of three independent experiments. 

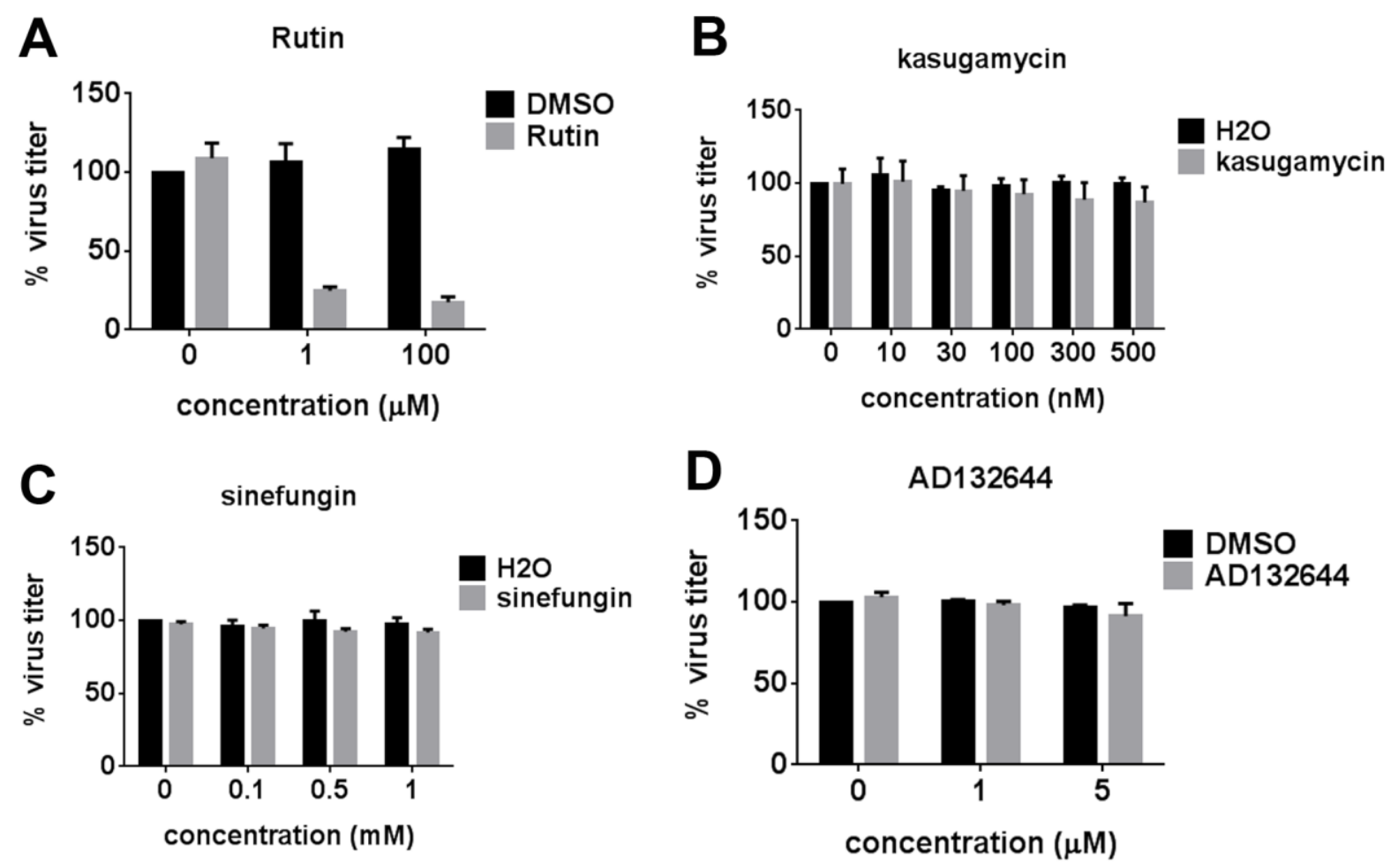

Figure 2. Antiviral efficacy of predicted RdRp inhibitors. Raw 264.7 cells were infected with MNV-1 ( $\mathrm{MOI}$ of 2.0) for 8 hours in the presence of indicated concentrations of (a) rutin; (b) kasugamycin; (c) sinefungin; (d) AD132644. Viral titers were determined by plaque assay. Infected cells in the presence of the vehicle control were set to $100 \%$. There is a statistically significant difference between the rutin and vehicle control group $(P<0.05$, t test), but no significant difference between kasugamycin, sinefungin and AD132644 treatment and control groups. Data are presented as means \pm SE of three independent experiments. 
Table 1. Select candidates with highest docking scores ${ }^{\mathrm{a}}$ after computational screening.

\begin{tabular}{|l|l|l|l|l|}
\hline ZINC ID & MNV & HNV & Price & Popular name \\
\hline Score & Score & $(\$) / \mu$ mol & \\
\hline ZINC28639308 & -12.1 & -10.5 & 38 & AD132644 \\
\hline ZINC11726792 & -9.8 & -9.6 & 17 & Sinefungin \\
\hline ZINC72206342 & -9.7 & -9.2 & 0.001 & Rutin \\
\hline ZINC08143614 & -9.7 & -7.2 & 1.32 & Ouabain \\
\hline ZINC04216676 & -9.1 & -8.4 & not avail. & Kaempferitrin \\
\hline ZINC26143524 & -9.1 & -6.8 & 163 & Tezosentan \\
\hline ZINC33359852 & -8.9 & -8.1 & 27 & Lymecycline \\
\hline ZINC04097715 & -8.8 & -9.9 & 4 & Antirrhinin \\
\hline ZINC04216682 & -8.5 & -10.4 & 0.01 & Kasugamycin \\
\hline ZINC03869383 & -8.4 & -8.9 & 1 & (none) \\
\hline ZINC01902827 & -8.1 & -9.1 & 15 & Fidexaban \\
\hline ZINC01910616 & -8.1 & -8.6 & 5 & Dabigatran \\
\hline ZINC03993831 & -7.9 & -8.7 & 81 & Amikacin \\
\hline ZINC08214483 & -7.9 & -10.9 & 0.03 & (none) \\
\hline ZINC53684226 & -7.4 & -8.9 & 2 & 7 \\
\hline
\end{tabular}

${ }^{a}$ Docking scores are estimations of the binding free energy in $\mathrm{kcal} / \mathrm{mol}$.

${ }^{\mathrm{b}}$ Mean docking scores for murine norovirus (MNV) RdRp between the three chains of PDB 3UPF.

${ }^{c}$ Docking scores for human norovirus (HNV) Norwalk virus RdRp from PDB 1SH2. 



\section{References}

1. (2012) QM-Polarized Ligand Docking protocol. Schrödinger Suite 2012. Schrödinger, LLC, New York, NY

2. (2012) Suite 2012: Glide. Schrödinger, LLC New York, NY

3. Arias A, Emmott E, Vashist S, Goodfellow I (2013) Progress towards the prevention and treatment of norovirus infections. Future Microbiol 8:1475-1487

4. Blanton LH, Adams SM, Beard RS, Wei G, Bulens SN, Widdowson MA, Glass RI, Monroe SS (2006) Molecular and epidemiologic trends of caliciviruses associated with outbreaks of acute gastroenteritis in the United States, 2000-2004. The Journal of infectious diseases 193:413-421

5. Butler M, Ng CY, van Heel DA, Lombardi G, Lechler R, Playford RJ, Ghosh S (2006) Modulation of dendritic cell phenotype and function in an in vitro model of the intestinal epithelium.

European journal of immunology 36:864-874

6. Chang KO, Takahashi D, Prakash O, Kim Y (2012) Characterization and inhibition of norovirus proteases of genogroups I and II using a fluorescence resonance energy transfer assay. Virology 423:125-133

7. Cho AE, Guallar V, Berne BJ, Friesner R (2005) Importance of accurate charges in molecular docking: quantum mechanical/molecular mechanical (QM/MM) approach. J Comput Chem 26:915-931

8. Costantini VP, Whitaker T, Barclay L, Lee D, McBrayer TR, Schinazi RF, Vinje J (2012) Antiviral activity of nucleoside analogues against norovirus. Antiviral therapy 17:981-991

9. Deschner EE, Ruperto, J.F., Wong, G.Y., Newmark, H.L. (1993) The effect of dietary quercetin and rutin on AOM-induced acute colonic epithelial abnormalities in mice fed a high-fat diet. Nutrition and Cancer 20:199-204

10. Dhanak D, Duffy KJ, Johnston VK, Lin-Goerke J, Darcy M, Shaw AN, Gu B, Silverman C, Gates AT, Nonnemacher MR, Earnshaw DL, Casper DJ, Kaura A, Baker A, Greenwood C, Gutshall LL, Maley D, DelVecchio A, Macarron R, Hofmann GA, Alnoah Z, Cheng HY, Chan G, Khandekar S, Keenan RM, Sarisky RT (2002) Identification and biological characterization of heterocyclic inhibitors of the hepatitis C virus RNA-dependent RNA polymerase. The Journal of biological chemistry 277:38322-38327

11. Duizer E, Schwab KJ, Neill FH, Atmar RL, Koopmans MP, Estes MK (2004) Laboratory efforts to cultivate noroviruses. The Journal of general virology 85:79-87

12. Feng $X$, Jiang X (2007) Library screen for inhibitors targeting norovirus binding to histo-blood group antigen receptors. Antimicrobial agents and chemotherapy 51:324-331

13. Friesner RA, Banks JL, Murphy RB, Halgren TA, Klicic JJ, Mainz DT, Repasky MP, Knoll EH, Shelley M, Perry JK, Shaw DE, Francis P, Shenkin PS (2004) Glide: a new approach for rapid, accurate docking and scoring. 1. Method and assessment of docking accuracy. Journal of medicinal chemistry 47:1739-1749

14. Friesner RA, Murphy RB, Repasky MP, Frye LL, Greenwood JR, Halgren TA, Sanschagrin PC, Mainz DT (2006) Extra precision glide: docking and scoring incorporating a model of hydrophobic enclosure for protein-ligand complexes. Journal of medicinal chemistry 49:61776196 
15. Gonzalez-Hernandez MB, Bragazzi Cunha J, Wobus CE (2012) Plaque assay for murine norovirus. J Vis Exp:e4297

16. Gonzalez-Hernandez MJ, Pal A, Gyan KE, Charbonneau M-E, Showalter HD, Donato NJ, O'Riordan M, Wobus CE (2014) Chemical Derivatives of a Small Molecule Deubiquitinase Inhibitor Have Antiviral Activity against Several RNA Viruses. PLoS ONE 9:e94491

17. Green KY (2014) Norovirus infection in immunocompromised hosts. Clinical microbiology and infection : the official publication of the European Society of Clinical Microbiology and Infectious Diseases 20:717-723

18. Guardia T, Rotelli, A.E., Juarez, A.O., Pelzer, L. E. (2001) Anti-inflammatory properties of plant flavonoids. Effects of rutin, quercetin and hesperidin on adjuvant arthritis in rat. II Farmaco 56:683-687

19. Halgren TA, Murphy RB, Friesner RA, Beard HS, Frye LL, Pollard WT, Banks JL (2004) Glide: a new approach for rapid, accurate docking and scoring. 2. Enrichment factors in database screening. Journal of medicinal chemistry 47:1750-1759

20. Hall AJ, Lopman BA, Payne DC, Patel MM, Gastanaduy PA, Vinje J, Parashar UD (2013) Norovirus disease in the United States. Emerging infectious diseases 19:1198-1205

21. Irwin JJ, Shoichet BK (2005) ZINC--a free database of commercially available compounds for virtual screening. Journal of chemical information and modeling 45:177-182

22. Irwin JJ, Sterling T, Mysinger MM, Bolstad ES, Coleman RG (2012) ZINC: a free tool to discover chemistry for biology. Journal of chemical information and modeling 52:1757-1768

23. Karst SM, Wobus CE, Goodfellow IG, Green KY, Virgin HW (2014) Advances in norovirus biology. Cell host \& microbe 15:668-680

24. Kim Y, Lovell S, Tiew KC, Mandadapu SR, Alliston KR, Battaile KP, Groutas WC, Chang KO (2012) Broad-spectrum antivirals against $3 C$ or $3 C$-like proteases of picornaviruses, noroviruses, and coronaviruses. Journal of virology 86:11754-11762

25. Kinch MS, Haynesworth A, Kinch SL, Hoyer D (2014) An overview of FDA-approved new molecular entities: 1827-2013. Drug discovery today 19:1033-1039

26. Kroneman A, Vega E, Vennema H, Vinje J, White PA, Hansman G, Green K, Martella V, Katayama K, Koopmans M (2013) Proposal for a unified norovirus nomenclature and genotyping. Archives of virology

27. Laufer S, Holzgrabe U, Steinhilber D (2013) Drug discovery: a modern decathlon. Angew Chem Int Ed Engl 52:4072-4076

28. Lin JP, Yang JS, Lu CC, Chiang JH, Wu CL, Lin JJ, Lin HL, Yang MD, Liu KC, Chiu TH, Chung JG (2009) Rutin inhibits the proliferation of murine leukemia WEHI-3 cells in vivo and promotes immune response in vivo. Leuk Res 33:823-828

29. Lin YJ, Chang YC, Hsiao NW, Hsieh JL, Wang CY, Kung SH, Tsai FJ, Lan YC, Lin CW (2012) Fisetin and rutin as $3 C$ protease inhibitors of enterovirus $A 71$. Journal of virological methods 182:9398

30. Mandadapu SR, Weerawarna PM, Gunnam MR, Alliston KR, Lushington GH, Kim Y, Chang KO, Groutas WC (2012) Potent inhibition of norovirus 3CL protease by peptidyl alpha-ketoamides and alpha-ketoheterocycles. Bioorg Med Chem Lett 22:4820-4826

31. Mastrangelo E, Pezzullo M, Tarantino D, Petazzi R, Germani F, Kramer D, Robel I, Rohayem J, Bolognesi M, Milani M (2012) Structure-Based Inhibition of Norovirus RNA-Dependent RNA Polymerases. Journal of molecular biology

32. Mullard A (2012) Drug repurposing programmes get lift off. Nature reviews Drug discovery 11:505-506 
33. Ng KK, Pendas-Franco N, Rojo J, Boga JA, Machin A, Alonso JM, Parra F (2004) Crystal structure of norwalk virus polymerase reveals the carboxyl terminus in the active site cleft. The Journal of biological chemistry 279:16638-16645

34. Patel MM, Widdowson MA, Glass RI, Akazawa K, Vinje J, Parashar UD (2008) Systematic literature review of role of noroviruses in sporadic gastroenteritis. Emerging infectious diseases 14:1224-1231

35. Rademacher C, Guiard J, Kitov PI, Fiege B, Dalton KP, Parra F, Bundle DR, Peters T (2011) Targeting norovirus infection-multivalent entry inhibitor design based on NMR experiments. Chemistry 17:7442-7453

36. Reuters T (2012) Knowledge-based drug repositioning to drive R\&D productivity. White paper. Thompson Reuters

37. Riggs BL, Hartmann LC (2003) Selective estrogen-receptor modulators -- mechanisms of action and application to clinical practice. The New England journal of medicine 348:618-629

38. Rocha-Pereira J, Cunha R, Pinto DC, Silva AM, Nascimento MS (2010) (E)-2-styrylchromones as potential anti-norovirus agents. Bioorganic \& medicinal chemistry 18:4195-4201

39. Rocha-Pereira J, Jochmans D, Debing Y, Verbeken E, Nascimento MS, Neyts J (2013) The Viral Polymerase Inhibitor 2'-C-Methylcytidine Inhibits Norwalk Virus Replication and Protects against Norovirus-Induced Diarrhea and Mortality in a Mouse Model. Journal of virology 87:11798-11805

40. Sardana D, Zhu C, Zhang M, Gudivada RC, Yang L, Jegga AG (2011) Drug repositioning for orphan diseases. Briefings in bioinformatics 12:346-356

41. Scallan E, Hoekstra RM, Angulo FJ, Tauxe RV, Widdowson MA, Roy SL, Jones JL, Griffin PM (2011) Foodborne illness acquired in the United States--major pathogens. Emerging infectious diseases 17:7-15

42. Subba-Reddy CV, Goodfellow I, Kao CC (2011) VPg-primed RNA synthesis of norovirus RNAdependent RNA polymerases by using a novel cell-based assay. Journal of virology 85:1302713037

43. Thackray LB, Wobus CE, Chachu KA, Liu B, Alegre ER, Henderson KS, Kelley ST, Virgin IV HW (2007) Murine noroviruses comprising a single genogroup exhibit biological diversity despite limited sequence divergence. Journal of virology 81:10460-10473

44. Tiew KC, He G, Aravapalli S, Mandadapu SR, Gunnam MR, Alliston KR, Lushington GH, Kim Y, Chang KO, Groutas WC (2011) Design, synthesis, and evaluation of inhibitors of Norwalk virus 3C protease. Bioorg Med Chem Lett 21:5315-5319

45. Treanor JJ, Atmar RL, Frey SE, Gormley R, Chen WH, Ferreira J, Goodwin R, Borkowski A, Clemens R, Mendelman PM (2014) A Novel Intramuscular Bivalent Norovirus Virus-Like Particle Vaccine Candidate-Reactogenicity, Safety, and Immunogenicity in a Phase 1 Trial in Healthy Adults. The Journal of infectious diseases

46. Vogel VG, Costantino JP, Wickerham DL, Cronin WM, Cecchini RS, Atkins JN, Bevers TB, Fehrenbacher L, Pajon ER, Jr., Wade JL, 3rd, Robidoux A, Margolese RG, James J, Lippman SM, Runowicz CD, Ganz PA, Reis SE, McCaskill-Stevens W, Ford LG, Jordan VC, Wolmark N, National Surgical Adjuvant B, Bowel P (2006) Effects of tamoxifen vs raloxifene on the risk of developing invasive breast cancer and other disease outcomes: the NSABP Study of Tamoxifen and Raloxifene (STAR) P-2 trial. JAMA 295:2727-2741

47. Wobus CE, Karst SM, Thackray LB, Chang KO, Sosnovtsev SV, Belliot G, Krug A, Mackenzie JM, Green KY, Virgin HW (2004) Replication of Norovirus in cell culture reveals a tropism for dendritic cells and macrophages. PLoS Biol 2:e432 
48. Xu K, Cote TR (2011) Database identifies FDA-approved drugs with potential to be repurposed for treatment of orphan diseases. Briefings in bioinformatics 12:341-345

49. Yanga J, Juan Guoa, J., Yuan, J. (2008) In vitro antioxidant properties of rutin. LWT - Food Science and Technology 41:1060-1066

50. Yunus MA, Lin X, Bailey D, Karakasiliotis I, Chaudhry Y, Vashist S, Zhang G, Thorne L, Kao CC, Goodfellow I (2015) The murine norovirus core subgenomic RNA promoter consists of a stable stem-loop that can direct accurate initiation of RNA synthesis. Journal of virology 89:12181229

51. Zamyatkin DF, Parra F, Alonso JM, Harki DA, Peterson BR, Grochulski P, Ng KK (2008) Structural insights into mechanisms of catalysis and inhibition in Norwalk virus polymerase. The Journal of biological chemistry 283:7705-7712 